\title{
Upgrading of biomass monosaccharides by immobilized glucose dehydrogenase and xylose dehydrogenase
}

Zdarta, Jakub; Pinelo, Manuel; Jesionowski, Teofil; Meyer, Anne S.

Published in:

ChemCatChem

Link to article, DOI:

$10.1002 /$ cctc. 201801335

Publication date:

2018

Document Version

Peer reviewed version

Link back to DTU Orbit

Citation (APA):

Zdarta, J., Pinelo, M., Jesionowski, T., \& Meyer, A. S. (2018). Upgrading of biomass monosaccharides by immobilized glucose dehydrogenase and xylose dehydrogenase. ChemCatChem, 10(22), 5164-5173. https://doi.org/10.1002/cctc.201801335

\section{General rights}

Copyright and moral rights for the publications made accessible in the public portal are retained by the authors and/or other copyright owners and it is a condition of accessing publications that users recognise and abide by the legal requirements associated with these rights.

- Users may download and print one copy of any publication from the public portal for the purpose of private study or research.

- You may not further distribute the material or use it for any profit-making activity or commercial gain

- You may freely distribute the URL identifying the publication in the public portal 
Heterogeneous \& Homogeneous \& Bio- \& NanoCHEMCATCHEM CATALYSIS

\section{Accepted Article}

Title: Upgrading of biomass monosaccharides by immobilized glucose dehydrogenase and xylose dehydrogenase

Authors: Jakub Zdarta, Manuel Pinelo, Teofil Jesionowski, and Anne Meyer

This manuscript has been accepted after peer review and appears as an Accepted Article online prior to editing, proofing, and formal publication of the final Version of Record (VoR). This work is currently citable by using the Digital Object Identifier (DOI) given below. The VoR will be published online in Early View as soon as possible and may be different to this Accepted Article as a result of editing. Readers should obtain the VoR from the journal website shown below when it is published to ensure accuracy of information. The authors are responsible for the content of this Accepted Article.

To be cited as: ChemCatChem 10.1002/cctc.201801335

Link to VoR: http://dx.doi.org/10.1002/cctc.201801335 


\title{
Upgrading of biomass monosaccharides by immobilized glucose dehydrogenase and xylose dehydrogenase
}

\author{
Jakub Zdarta ${ }^{*[a, b]}$, Manuel Pinelo ${ }^{[b]}$, Teofil Jesionowski ${ }^{[a]}$, Anne S. Meyer ${ }^{[b]}$
}

\begin{abstract}
Direct upgrading and separation of the monosaccharides from biomass liquors is an overlooked area. In this work we demonstrate enzymatic production of gluconic acid and xylonic acid from glucose and xylose present in pretreated birchwood liquor by glucose dehydrogenase (GDH, EC 1.1.1.118) and xylose dehydrogenase (XDH, EC 1.1.1.175), respectively. The biocatalytic conversions were compared using two different kinds of silica support materials (silica nanoparticles $\left(\mathrm{nanoSiO}_{2}\right)$ and porous silica particles with hexagonal pores (SBA silica) for enzyme immobilization. Upon immobilization, both enzymes showed significant improvement in their thermal stability and robustness at alkaline $\mathrm{pH}$ and exhibited over $50 \%$ activity even at $\mathrm{pH} 10$ and $60^{\circ} \mathrm{C}$ on both immobilization matrices. When compared to free enzymes at $45^{\circ} \mathrm{C}, \mathrm{GDH}$ immobilized on nanoSiO ${ }_{2}$ and SBA silica displayed a 4.5 and 7.25 fold increase in half-life, respectively, whilst $\mathrm{XDH}$ immobilized on nanoSiO2 and SBA showed a 4.7 and 9.5 fold improvement in half-life, respectively. Additionally, after five reaction cycles both nanoSiO $\mathrm{SDH}_{2}$ and nanoSiO $\mathrm{O}_{2} \mathrm{XDH}$ retained more than $40 \%$ activity and $\mathrm{GDH}$ and $\mathrm{XDH}$ immobilized on SBA silica maintained around $50 \%$ of their initial activity resulting in about 1.5-1.6 fold increase in biocatalytic productivity compared to the free enzymes.
\end{abstract}

\section{Introduction}

Bio-based conversion of biomass components by soluble or immobilized enzymes has been presented as a promising and efficient approach for sustainable production of valuable chemical compounds under mild reaction conditions ${ }^{[1,2]}$. Use of glucose dehydrogenase (GDH) (EC 1.1.1.118) and xylose dehydrogenase $(\mathrm{XDH})$ (EC 1.1.1.175) is of interest in this regard because these NAD+ dependent enzymes catalyze conversion of D-glucose into gluconic acid and D-xylose into xylonic acid, respectively ${ }^{[3]}$. Besides transformation of monosaccharides, the enzymatic conversion adds a charge to the products, which can facilitate separation of acid products from a mixed product stream, for instance using membrane technology $y^{[4]}$. Both gluconic acid and xylonic acid are classified by the US Department of Energy among the top 30 potential high-value

[a] Dr Jakub Zdarta, Prof. Teofil Jesionowski Institute of Chemical Technology and Engineering, Faculty of Chemical Technology,

Poznan University of Technology

Berdychowo 4, PL-60965 Poznan, Poland

E-mail: jakub.zdarta@put.poznan.pl

[b] Dr Jakub Zdarta, Prof. Manuel Pinelo, Prof. Anne S. Meyer

Center for BioProcess Engineering, Department of Chemical and

Biochemical Engineering

Technical University of Denmark,

SoltoftsPlads 229, DK-2800 Kgs. Lyngby, Denmark compounds from biomass ${ }^{[5]}$. Gluconic acid is a mild organic acid that has multiple applications in the food industry but also in pharmaceuticals synthesis ${ }^{[6]}$. Xylonic acid is used as a substrate for synthesis of 1,2,4-butanetriol and 1,2,4-butanetriol trinitrate $e^{[7]}$ and has moreover been projected for various uses in the food, pharmaceutical and agriculture industries ${ }^{[8]}$. However, the practical biocatalytic conversion of biomass components using $\mathrm{GDH}$ and $\mathrm{XDH}$ is limited due to their relatively low stability at extreme $\mathrm{pH}$ and temperature conditions.

A possible approach to overcome these limitations and at the same time increase the biocatalytic productivity via maximizing enzyme "reuse" is enzyme immobilization ${ }^{[4,9]}$. Enzyme immobilization may moreover reduce the complexity of enzyme separation from the products after reaction ${ }^{[6,10]}$. Various techniques and methods of immobilization such as adsorption, covalent binding, entrapment or encapsulation have been described previously ${ }^{[11-13]}$. Silica-based materials are frequently used as support materials in enzyme immobilization due to their thermal, chemical and mechanical resistance, good sorption properties, and the presence of many hydroxyl groups that facilitate enzyme binding ${ }^{[14-16]}$. Moreover, silica-based materials are easy to obtain and relatively cheap, a feature of particular significance in biomass valorization processes. Nonetheless, data related to immobilization of glucose dehydrogenase and xylose dehydrogenase on silica are limited.

As data about immobilization of glucose dehydrogenase and xylose dehydrogenase are limited, a simple protocol is required to use efficient and stable support materials for immobilization of $\mathrm{GDH}$ and $\mathrm{XDH}$ which additionally facilitating further separation of products of enzymatic conversion. Thus, in the present study, we examine immobilization, characterization and comparison of $\mathrm{GDH}$ and XDH on two types of silica support materials - silica nanoparticles and mesoporous silica with hexagonally ordered pores. As part of the study, we also investigate the kinetics of the enzymatic conversions of monosaccharides, and examine the effect of various $\mathrm{pH}$ and temperature conditions on free and immobilized GDH and XDH and evaluate the influence of these parameters on the enzyme stability. The practical application of the biocatalytic systems is validated by applying them for conversion of glucose and xylose present in authentic pretreated birch wood biomass liquors.

\section{Results and Discussion}

\section{GDH and XDH immobilization}

In this study, silica nanopowder of particle size in the range of $10-20 \mathrm{~nm}$ and pore diameters of around $2 \mathrm{~nm}$ size (nanoSiO ${ }_{2}$ ) and mesoporous SBA 15 silica ( $<150 \mu \mathrm{m}$ particle size) with hexagonal pore morphology and pore size up to $20 \mathrm{~nm}$ (SBA15) were used. It should be emphasized that type of the support material is known to affect place of enzyme binding. According to the previously published articles, using silica nanoparticles, 
$\mathrm{GDH}$ and $\mathrm{XDH}$ are expected to be immobilized on the particle surfaces, while in case of SBA silica, biomolecules are presumably bound mainly inside the SBA 15 silica pores, as it is schematically presented in Fig. $1^{[14,15]}$. (a)

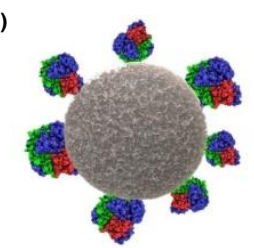

(b)

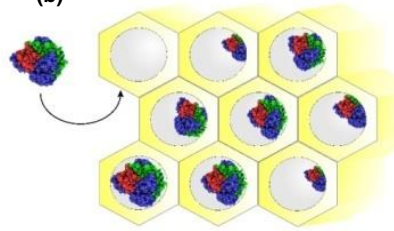

Figure 1. Schematic presentation of immobilization of glucose dehydrogenase and/or xylose dehydrogenase: (a) on silica nanoparticles and (b) in pores of hexagonal mesoporous silica.

These expectations were confirmed by the images from transmission electron microscopy and changes of the porous structure parameters of silica-based materials after GDH and $\mathrm{XDH}$ immobilization (Fig. 2 and Table 1). After immobilization of both enzymes surface area of the nanoSiO ${ }_{2}$ decreased around two times and reached about $120 \mathrm{~m}^{2} / \mathrm{g}$ as its pore size was unaltered after enzyme binding. Surface area of SBA 15 silica was intact after immobilization, meanwhile significant changes were noticed in pore size and pore volume indicating GDH and $\mathrm{XDH}$ immobilization into the pores of the hexagonal silica.

Table 1. Porous structure parameters of nanoSiO $\mathrm{S}_{2}$ silica and hexagonal mesoporous silica SBA 15 before and after immobilization of glucose dehydrogenase or xylose dehydrogenase.

\begin{tabular}{|c|c|c|c|}
\hline Sample name & $\begin{array}{l}\text { BET surface } \\
\text { area }\left(\mathrm{m}^{2} / \mathrm{g}\right)\end{array}$ & $\begin{array}{l}\text { Pore volume } \\
\left(\mathrm{cm}^{3} / \mathrm{g}\right)\end{array}$ & $\begin{array}{c}\text { Pore size } \\
\text { (nm) }\end{array}$ \\
\hline nanoSiO ${ }_{2}$ & 219.6 & 0.098 & 2.048 \\
\hline nanoSiO ${ }_{2}$ GDH & 118.3 & 0.087 & 2.046 \\
\hline nanoSiO ${ }_{2}$ XDH & 121.6 & 0.091 & 2.047 \\
\hline SBA15 & 579.6 & 0.868 & 19.211 \\
\hline SBA15GDH & 567.2 & 0.476 & 14.754 \\
\hline SBA15XDH & 570.2 & 0.513 & 15.634 \\
\hline
\end{tabular}
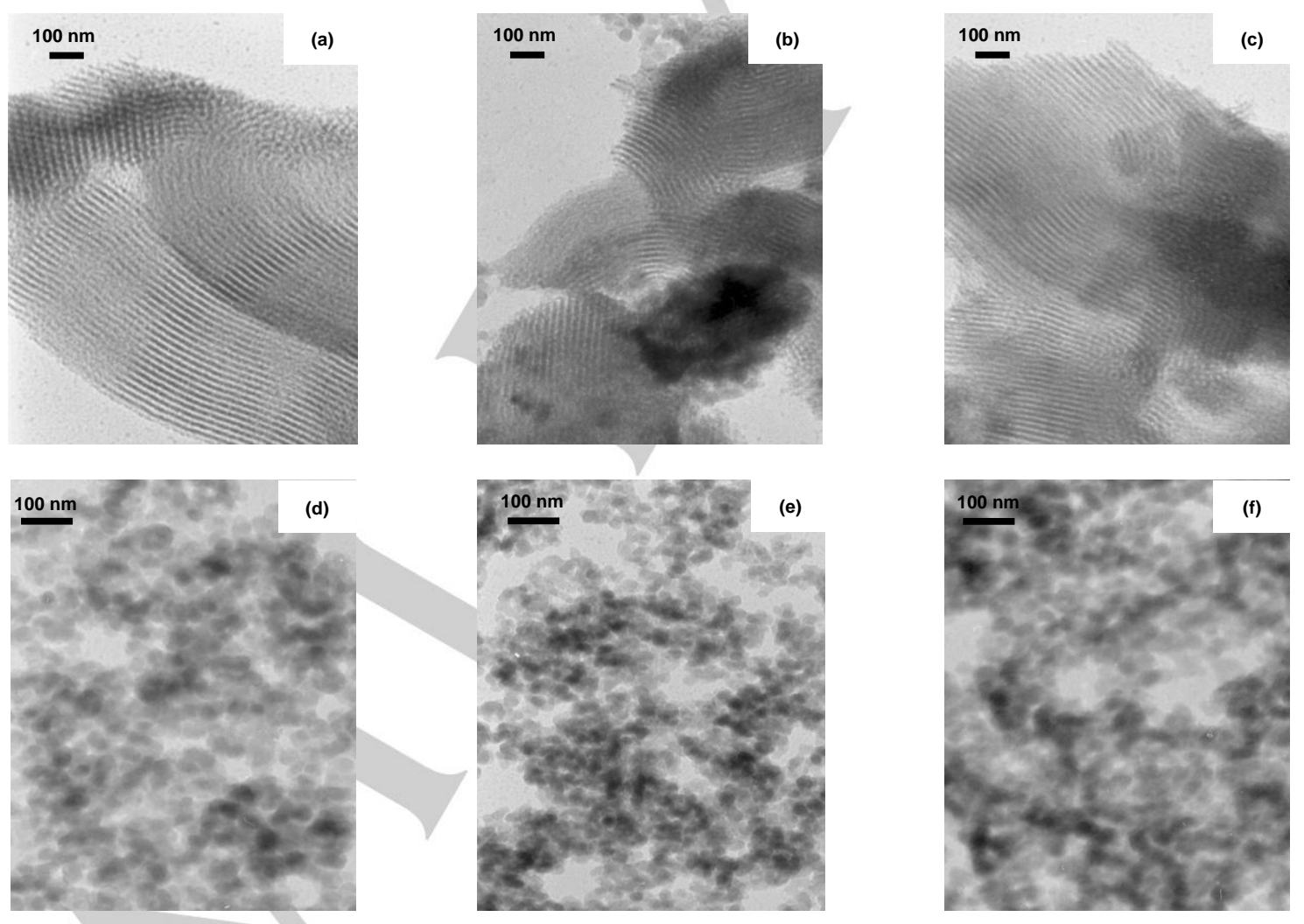

Figure 2. TEM images of the: (a) SBA 15 silica and (b) nanoSiO ${ }_{2}$ silica before enzyme immobilization; (b) and (e) after immobilization of glucose dehydrogenase; (c) and (f) after immobilization of xylose dehydrogenase.
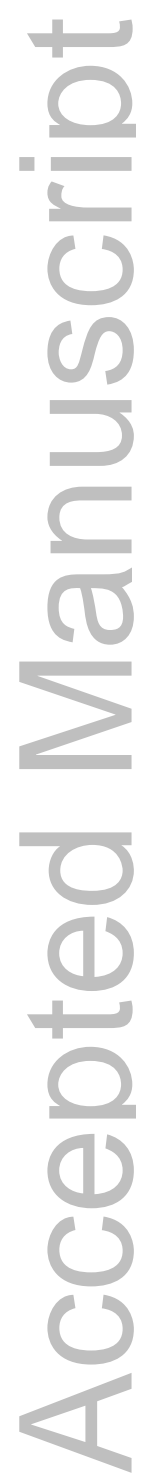
Table 2. Immobilization yield and amount of immobilized enzyme in different biocatalytic systems. Specific activity and activity retention of free and immobilized GDH and XDH.

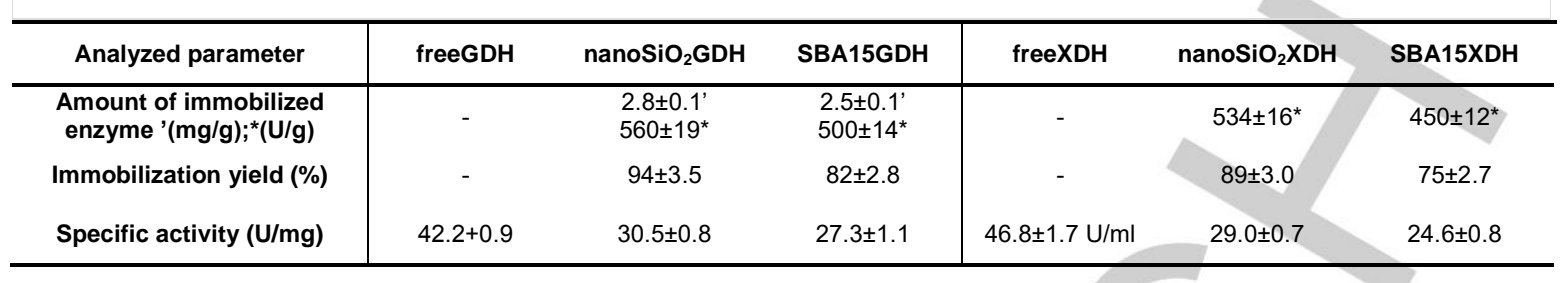

The different ways of immobilization were thus anticipated to produce different amounts of immobilized enzymes, highest on the nanoparticles due to their high surface area: $2.8 \mathrm{mg} \mathrm{(560} \mathrm{U)}$ of $\mathrm{GDH}$ and $534 \mathrm{U}$ of $\mathrm{XDH}$ were immobilized on $1 \mathrm{~g}$ of nanoSiO which was about 10-15\% higher compared with SBA 15 (Table 2). Immobilization yield also followed this trend: when nanoSiO $\mathrm{S}_{2}$ was used, immobilization yield for $\mathrm{GDH}$ and $\mathrm{XDH}$ reached 94 and $82 \%$, whereas for SBA 15 it was 89 and $75 \%$, respectively, Hence, irrespective of the support material, a higher quantity of the immobilized enzyme was noticed in case of glucose dehydrogenase. Greater amounts of immobilized $\mathrm{GDH}$, as compared to $\mathrm{XDH}$, are probably related to the threedimensional structure and amino acids composition of this enzyme ${ }^{[17]}$. A possible explanation for this is that enzymes molecules possessing more accessible amino acids in their structure, like arginine, asparagine, glutamic acid or lysine are more effectively immobilized, as it was previously reported for glucose-6-phosphate dehydrogenase ${ }^{[18]}$. Nevertheless, both enzymes are linked to the silica by adsorption immobilization, by creation of electrostatic interactions and hydrogen bonds between mainly amino $\left(-\mathrm{NH}_{2}\right)$, hydroxyl $(-\mathrm{OH})$ and carbonyl $(-\mathrm{COOH})$ groups of the enzymes and hydroxyl groups of the silica-based support.

The specific activity of $\mathrm{GDH}$ and $\mathrm{XDH}$ was $42.2 \mathrm{U} / \mathrm{mg}$ and $46.8 \mathrm{U} / \mathrm{ml}$, respectively, indicating that both enzymes showed similar catalytic activity in model reaction. The specific activity of the immobilized enzymes was lower and reached 30.5 and $27.3 \mathrm{U} / \mathrm{mg}$ of the enzyme, respectively, for nanoSiO $\mathrm{S}_{2} \mathrm{GDH}$ and SBA15GDH, which corresponded to an activity retention of 72.3 and $64.7 \%$, respectively. For nanoSiO ${ }_{2} \mathrm{XDH}$ and SBA15XDH, these values were slightly lower and reached 29.0 and $24.6 \mathrm{U} / \mathrm{mg}$, respectively. Also noticed was a lower activity retention of $61.8 \%$ for nanoSiO ${ }_{2} \mathrm{XDH}$ and $52.6 \%$ for SBA15XDH. The lower values of specific activity and activity retention noticed for enzymes immobilized onto SBA 15 compared with nanoSiO $\mathrm{S}_{2}$, might be explained by two factors: (i) lower amount of immobilized biocatalysts and (ii) hindered accessibility of the enzyme active sites for the substrates molecules due to immobilization of enzymes mainly into the pores of the support. Nevertheless, lower activity of immobilized $\mathrm{XDH}$ compared with $\mathrm{GDH}$ is probably related to the larger conformational changes of 3-D biomolecule structure that occur upon immobilization, as reported earlier by Li et al. ${ }^{[19]}$.

There is no available literature about efficient immobilization of $\mathrm{XDH}$, and though there are some reports about immobilization of $\mathrm{GDH}$, results presented here go further than previously published data. For example, Baron et al. used controlled pore silica with average pore size of $500 \AA$, as a support for Bacillus megaterium glucose dehydrogenase and immobilized less than $0.5 \mathrm{mg}$ of enzyme per $1 \mathrm{~g}$ of the support ${ }^{[20]}$, whereas here we report a loading capacity of silica nanoparticles of $2.8 \mathrm{mg} / \mathrm{g}$, probably due to higher density of hydroxyl groups on the surface of nanoSiO . .

\section{Effect of temperature and pH on activity and stability of free and immobilized GDH}

Free $\mathrm{GDH}$ as well as both of the $\mathrm{GDH}$-based, immobilized systems exhibited the highest activity at $45^{\circ} \mathrm{C}$ (Fig. 3a). At temperatures below optimum, free GDH was characterized by slightly higher, but significantly different, activity than the immobilized enzyme. But at higher temperatures $\left(45-60^{\circ} \mathrm{C}\right)$, immobilized GDH showed better activity than the free biocatalyst. This is particularly noticeable in the case of the mesoporous SBA 15 silica support and GDH immobilized on this material showed higher residual activity $(53 \%)$ than free enzyme $(29 \%)$ even at a temperature of $60^{\circ} \mathrm{C}$. GDH is known as an enzyme that exhibits catalytic activity only in multimeric form. In a previous study, it has been shown that at temperatures above $50^{\circ} \mathrm{C}$, multimers tend to dissociate, which leads to irreversible inactivation ${ }^{[21]}$. Since immobilization using silica provided enzymes multipoint attachment and improved rigidity of the enzyme, thermal dissociation of silica-bounded GDH multimers could be prevented that lead to better activity retention at higher temperatures.

Free and silica immobilized GDH showed similar $\mathrm{pH}$ profiles which were, however, statistically significantly different over whole analyzed $\mathrm{pH}$ range (6-10), as illustrated in Fig. 3b. However, nanoSiO ${ }_{2} \mathrm{GDH}$ and SBA15GDH exhibited about 10 and $15 \%$ enhancement of catalytic activity, respectively, particularly at basic conditions (8.5-10), compared to free catalysts. A shift of the pH optima from 8 (free GDH) to 8.5 (immobilized $\mathrm{GDH}$ ) was also observed. Changes in the $\mathrm{pH}$ and temperature profiles could be explained by the fact that immobilization, in general, leads to conformational changes of the structure of the enzyme ${ }^{[22]}$. These changes occur mainly as a result of ionization of side chains of active site amino acids. However, type, nature and functional group of the matrix also play a significant role. These factors lead to modifications of microenvironment around the active site of the enzyme and in consequence affect the $\mathrm{pH}$ and temperature profile of the immobilized biocatalysts ${ }^{[23]}$.

Evaluation of the thermal stability of the immobilized enzyme is a crucial step in determining practical applications of the produced biocatalytic systems. Binding of GDH to the silica support significantly improved thermal stability of the enzyme: 
after $45 \mathrm{~min}$ of heating at $45^{\circ} \mathrm{C}$, at $\mathrm{pH} 8$, free enzyme maintained $42.5 \%$ of its activity, while nanoSiO${ }_{2} \mathrm{GDH}$ and SBA15GDH retained 47 and $53 \%$ of catalytic activity, respectively (Fig. 3c). Moreover, after $210 \mathrm{~min}$ of incubation under the same conditions, no catalytic activity was observed for free GDH whereas immobilized enzyme was more stable and retained about 30 and $35 \%$ of its activity when immobilized using nanoSiO ${ }_{2}$ and SBA silica, respectively that might be explained by creation of a more suitable microenvironment after immobilization as reported also by $\mathrm{Li}$ et al. ${ }^{[24]}$. Since drop in the relative activity of free $\mathrm{GDH}$ could be explained mainly by thermal and chemical inactivation of the biocatalyst, decrease in the activity of the immobilized enzyme could also partially reflect leakage of GDH from the matrix. Nevertheless, the higher relative activity noticed for SBA15GDH, as compared to nanoSiO ${ }_{2} \mathrm{GDH}$, is related to catalyst immobilization in the hexagonal pores of the support, which ensures better protection of the enzyme molecules against harsh reaction conditions.

(a)

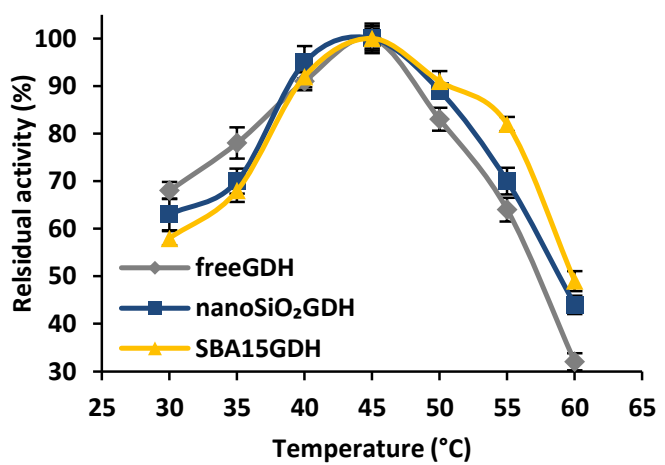

(c)

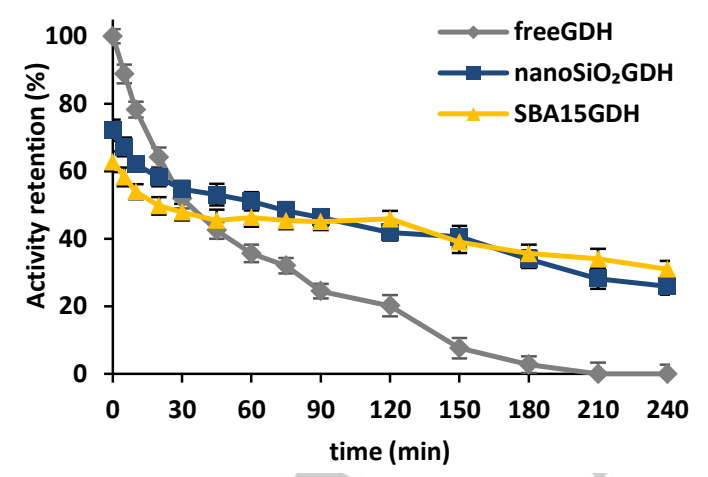

Significant improvement in the stability of the immobilized GDH can also be observed in values of the inactivation constant $\left(k_{D}\right)$ and enzyme half-life ( $t_{1 / 2}$ ) (Fig. $3 \mathrm{~d}$ ). $k_{D}$ and $t_{1 / 2}$ for free glucose dehydrogenase was found to be $0.01741 / \mathrm{min}$ and $39.8 \mathrm{~min}$, respectively, whereas inactivation constants of nanoSiO $\mathrm{S}_{2} \mathrm{GDH}$ and SBA15GDH were, respectively, 4.5 fold and 7.2 fold ( $0.00381 / \mathrm{min}$ and $0.00241 / \mathrm{min}$ ) lower than of those of the free enzyme. As a result, enzyme half-life was significantly improved and reached $182.4 \mathrm{~min}$ for nanoSiO${ }_{2} \mathrm{GDH}$ and $288.8 \mathrm{~min}$ for SBA15GDH. These findings are in agreement with data reported earlier by Twala et al. who immobilized GDH on functionalized ReSynTM polymer microspheres. However, in their study, immobilized enzyme half-life increased two fold after immobilization after incubation at $45^{\circ} \mathrm{C}$ compared to the free catalysts, while in the current study, enzyme half-life was improved much more (for about 4.5 fold). That is probably related to the more suitable chemical microenvironment created by the silica nanoparticles compared to polymeric support ${ }^{[1]}$.

(b)

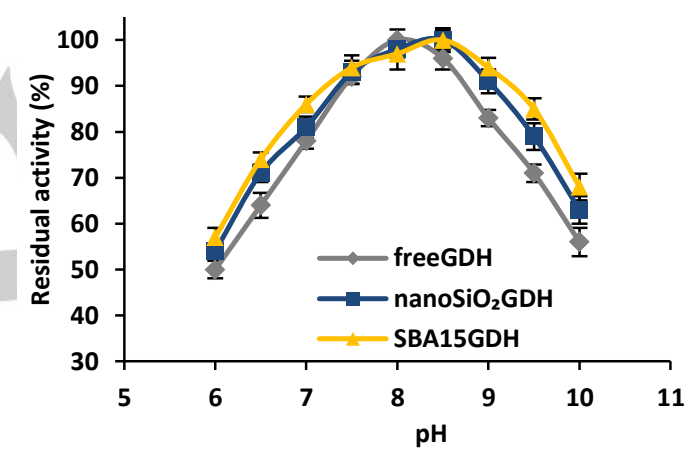

(d)

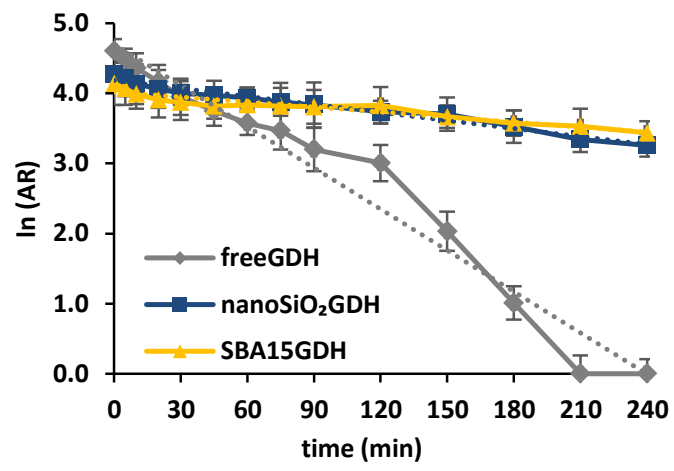

Figure 3. (a) temperature profiles, (b) pH profiles and (c, d) thermal stability of free and silica immobilized glucose dehydrogenase (GDH). Thermal stability of free and silica immobilized $\mathrm{GDH}$ was examined under optimal temperature $\left(45^{\circ} \mathrm{C}\right)$ and $\mathrm{pH}(8)$ conditions. Inactivation constants $\left(k_{D}\right)$ were evaluated based on the linear regression slope. All data are presented as means \pm standard deviation.

\section{Effect of temperature and $\mathrm{pH}$ on activity and stability of free and immobilized GDH}

The optimum temperature of free $\mathrm{XDH}$ was $40^{\circ} \mathrm{C}$, whereas for nanoSiO 2 XDH and $\mathrm{SBA} 15 \mathrm{XDH}$, the optimum shifted slightly upwards $\left(45^{\circ} \mathrm{C}\right)$ (Fig. 4). Temperature profiles of free and immobilized $\mathrm{XDH}$ were also statistically significantly different. At temperatures below maximum, free enzyme showed higher activity compared with immobilized enzymes. However, when temperature exceed $40^{\circ} \mathrm{C}$, activity of free enzyme dropped sharply while immobilized $\mathrm{XDH}$ retained significantly higher activities. At $65^{\circ} \mathrm{C}$ nanoSiO ${ }_{2} \mathrm{XDH}$ and $\mathrm{SBA} 15 \mathrm{XDH}$ retained 69 and $64 \%$, respectively, of their residual activity while free biocatalyst showed less than $50 \%$ residual activity. The higher temperature optimum recorded for immobilized $\mathrm{XDH}$ and the significant improvement of immobilized enzyme activity at higher temperatures are probably a result of creation of enzyme-matrix 
interactions that form external enzyme backbones and increase rigidity of the biocatalyst ${ }^{[25]}$. Such changes would have protected the active sites of the $\mathrm{XDH}$ against conformational changes and denaturation at higher temperatures, and thus help to maintain high catalytic activity.

All tested XDH systems exhibited their optimum at pH 8 (Fig. 3b) Moreover, their $\mathrm{pH}$ profiles were significantly different, however, particularly at $\mathrm{pH}$ values close to neutral (6.5-8.5), they were similar. Immobilization of $\mathrm{XDH}$ at basic $\mathrm{pH}(9-10)$ resulted in nanoSiO2XDH and SBA15XDH showing about 10 and $20 \%$ higher activity, respectively, compared to the free catalyst. Under strongly acidic or basic conditions, ionic groups presented in the enzyme structure might be protonated or deprotonated, respectively. These changes result in formation of electrostatic repulsion between these groups, and hence destruction and degeneration of the enzyme active site and decrease in catalytic properties of the enzyme ${ }^{[28]}$. Creation of the enzyme-matrix interactions which limit dissociation of enzyme subunits and stiffening the structure of the biomolecule after immobilization, caused that susceptibility of the enzyme to conformational changes in $\mathrm{pH}$ decreases, and leads to improvements of enzyme activity under harsh $\mathrm{pH}$ conditions.

Additionally, thermal stability of free and both silica-immobilized $\mathrm{XDH}$ was studied. Although, after immobilization activity decreased (Table 2), stability of immobilized $\mathrm{XDH}$ was improved compared to the free enzyme (Fig. 4c). After $180 \mathrm{~min}$ of incubation at $\mathrm{pH} 8$ and $40^{\circ} \mathrm{C}$, free enzyme completely lost its activity while nanoSiO${ }_{2} \mathrm{XDH}$ and $\mathrm{SBA} 15 \mathrm{XDH}$ retained more than $50 \%$ of their initial activity. Moreover, after $240 \mathrm{~min}$ of incubation at $45^{\circ} \mathrm{C}, \mathrm{XDH}$ immobilized on silica nanoparticles or in hexagonal silica retained over 25 and over $30 \%$ of activity, respectively. As stability and catalytic activity of the enzyme after immobilization were improved, inactivation constant $\left(k_{D}\right)$ and enzyme half-life $\left(t_{1 / 2}\right)$ were also enhanced (Fig. $\left.4 \mathrm{~d}\right) . k_{D}$ and $t_{1 / 2}$ of free enzyme reached $0.02371 / \mathrm{min}$ and $29.2 \mathrm{~min}$, respectively, while after immobilization on silica nanoparticles the values were $0.0051 / \mathrm{min}$ and $138.6 \mathrm{~min}$, respectively. When hexagonal SBA silica was used as support, an even higher enzyme half-life (277.2 $\mathrm{min})$ and lower inactivation constant $(0.00251 / \mathrm{min})$ were obtained. It might be explained by the fact that due to immobilization in the pores of the matrix, enzyme molecules are better protected compared to attachment of biocatalysts onto the surface of the matrix. Free enzyme on the other hand was subject to total inactivation due mainly to thermal and chemical and denaturation caused by heating and contact with base. However, negative effect of harsh reactive conditions on GDH and $\mathrm{XDH}$ was strongly hampered after enzyme immobilization due mainly to stabilization of the entire biocatalyst structure.
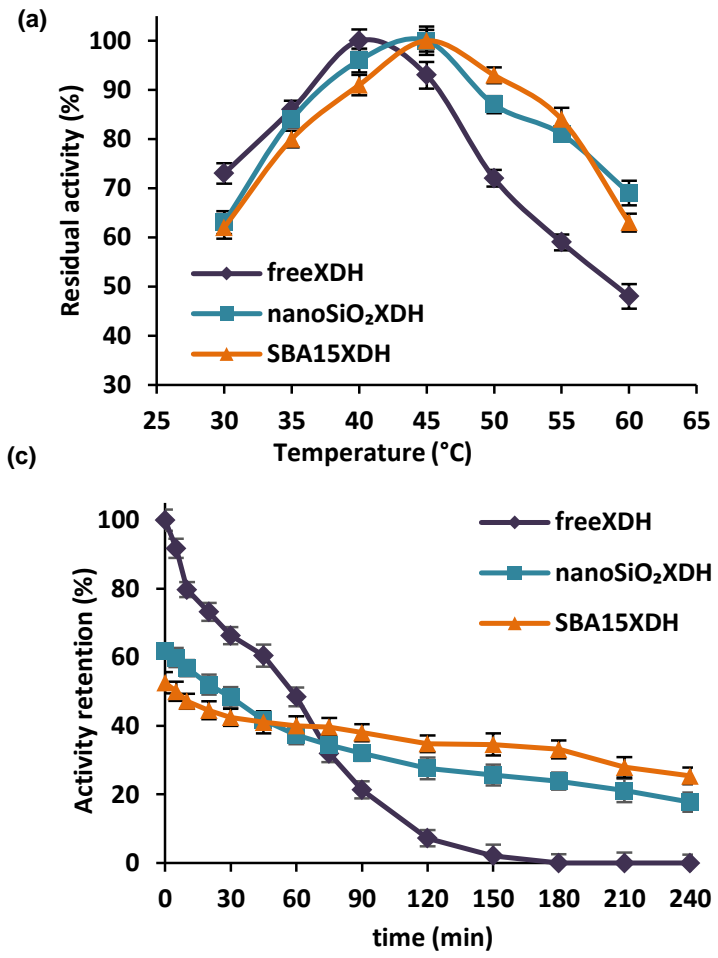

(b)
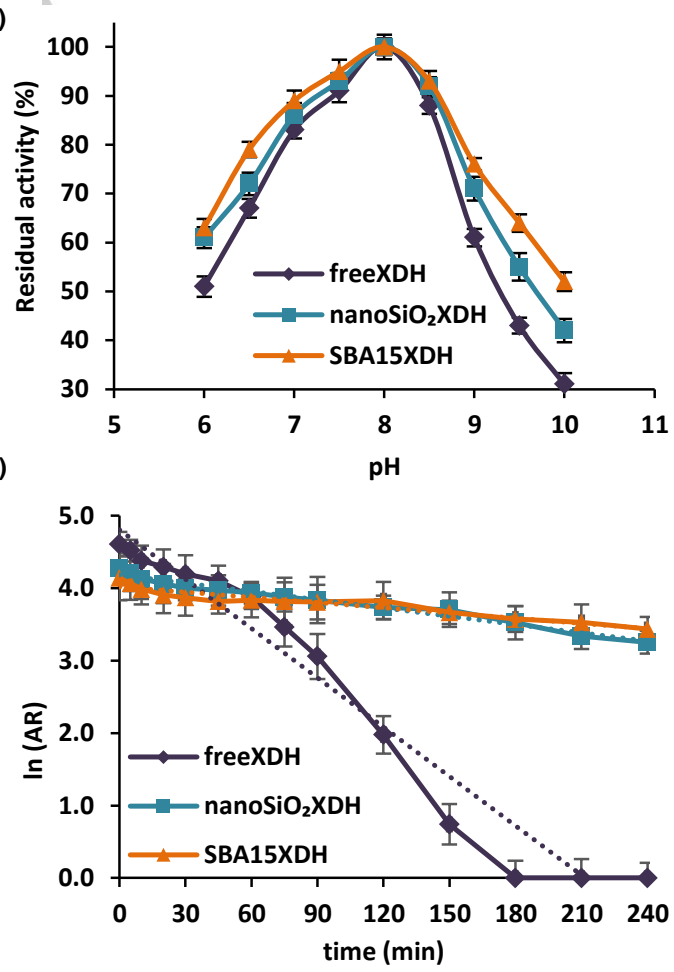

Figure 4. (a) temperature profiles, (b) pH profiles and (c, d) thermal stability of free and silica immobilized xylose dehydrogenase (XDH). Thermal stability of free and silica immobilized $\mathrm{XDH}$ was examined at optimal temperature $\left(40^{\circ} \mathrm{C}\right.$ for free enzyme and $45^{\circ} \mathrm{C}$ for immobilized enzymes) and pH (8) conditions. Inactivation constants $\left(k_{D}\right)$ were evaluated based on the linear regression slope. All data are presented as means \pm standard deviation. 
Table 3. Kinetic parameters for free and silica immobilized GDH and XDH.

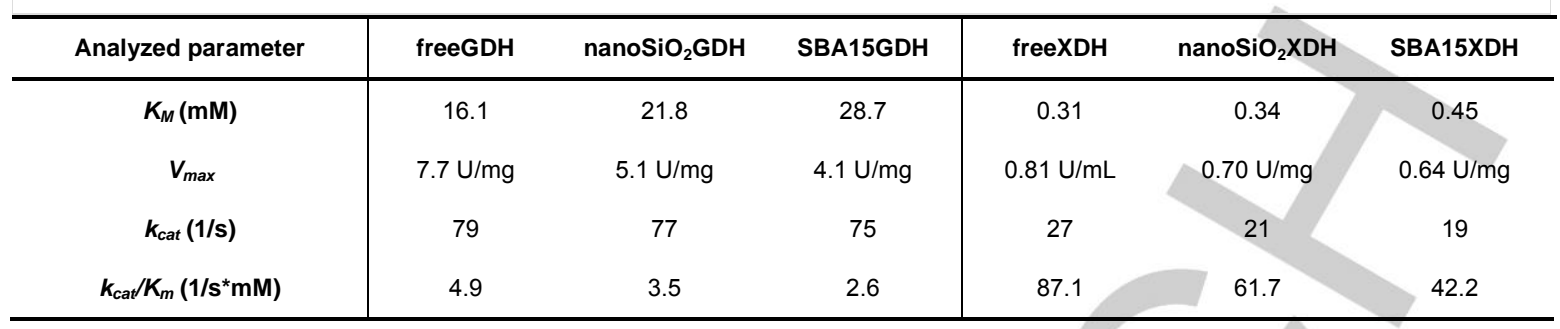

\section{Kinetic parameters of free and immobilized enzymes}

The $K_{M}$ Michaelis-Menten constant and the $V_{\max }$ for free GDH were found to be $16.1 \mathrm{mM}$ and $7.7 \mathrm{U} / \mathrm{mg}$, respectively. After immobilization $K_{M}$ increased and reached 21.8 and $28.7 \mathrm{mM}$ for nanoSiO $\mathrm{S}_{2} \mathrm{GDH}$ and $\mathrm{SBA} 15 \mathrm{GDH}$, respectively. Simultaneously, $V_{\text {max }}$ dropped 35 and $45 \%$ for nanoSiO ${ }_{2} \mathrm{GDH}$ and SBA15GDH, respectively, compared to free catalyst. Nevertheless, it should be underlined that turnover number of immobilized biocatalysts was maintained almost unaltered as $k_{\text {cat }}$ of nanoSiO ${ }_{2} \mathrm{GDH}$ and SBA15GDH were 97 and $94 \%$ of that of free GDH, respectively (Table 3). Since turnover numbers of free and immobilized glucose dehydrogenase are comparable, increase in $K_{M}$ value could be explained by the fact that after immobilization diffusional limitations occurred. As a result, active sites of the silica-bounded GDH are less accessible to the substrate and cofactor molecules, however, additional effects of cofactormatrix and substrate-matrix interactions cannot be excluded either ${ }^{[20]}$. Thus, as suggested earlier by Zhou et al., a higher concentration of substrates is required to enhance their interactions with immobilized catalysts ${ }^{[27]}$. Moreover, as a result of enzyme attachment to the support, some of the active sites could be blocked, which reduces reaction rate and leads to drop in the maximum reaction velocity $\left(V_{\max }\right)$ [30]. Baron et al., who immobilized GDH from Bacillus onto DEAE-Sephadex modified by glutaraldehyde, also made similar observations. However, in their study $K_{M}$ was 4 -fold greater after immobilization and $V_{\max }$ was simultaneously almost 4 -fold lower compared to the free enzyme ${ }^{[20]}$

The $K_{M}$ and $V_{\max }$ calculated for free $\mathrm{XDH}$ were $0.31 \mathrm{mM}$ and $0.81 \mathrm{U} / \mathrm{mL}$, respectively, and were comparable to those reported in our previous study where $V_{\max }$ has been found to be $0.56 \mathrm{U} / \mathrm{mL}$ [31]. The $K_{M}$ of nanoSiO ${ }_{2} \mathrm{XDH}$ and SBA15XDH were about 10 and $50 \%$ higher, respectively, compared with $K_{M}$ of free $\mathrm{XDH}$. However, the increase of $K_{M}$ after immobilization observed for $\mathrm{XDH}$ was less significant than for $\mathrm{GDH}$ immobilized in this study. Simultaneously, a less significant drop of $V_{\max }$ was also noticed for immobilized $\mathrm{XDH}$. These results could indicate that diffusional limitations that occurred after XDH immobilization were minimalized compared to $\mathrm{GDH}$ immobilization. This effect is probably related to the smaller molecular weight of $\mathrm{XDH}^{[17]}$. Nevertheless, the turnover number of nanoSiO ${ }_{2} \mathrm{XDH}$ and SBA15XDH were about 80 and $70 \%$, respectively, of that of the free enzyme, which suggested that some conformational changes in the structure of active site amino acids occurred upon immobilization ${ }^{[30]}$. These results support the data related to the retention of catalytic properties by immobilized $\mathrm{XDH}$ presented above (Table 2). It also should be emphasized that, irrespectively of the used enzyme, higher values of $K_{M}$ were noticed for enzymes immobilized using SBA silica, compared to nanoSiO $\mathrm{S}_{2}$, indicating lower substrate affinity to bounded $\mathrm{GDH}$ and $\mathrm{XDH}$. It is related to the fact that using mesoporous silica (SBA 15) higher diffusional limitations occurred because biomolecules are immobilized mainly into its pores, as in case of nanoSiO $\mathrm{S}_{2}$ enzyme is attached onto the surface of the support, as presented in Fig. 1.

\section{Conversion of biomass liquors}

Investigation of stability of free and immobilized enzymes was carried out based on model solutions of xylose and glucose. Thus, to evaluate practical applications of the biocatalytic systems produced, for conversion of glucose xylose two different real biomass solutions, (i) a stream of monosaccharides (glucose, xylose, arabinose) obtained after nanofiltration of PTL and (ii) pretreated liquor (PTL), were used.

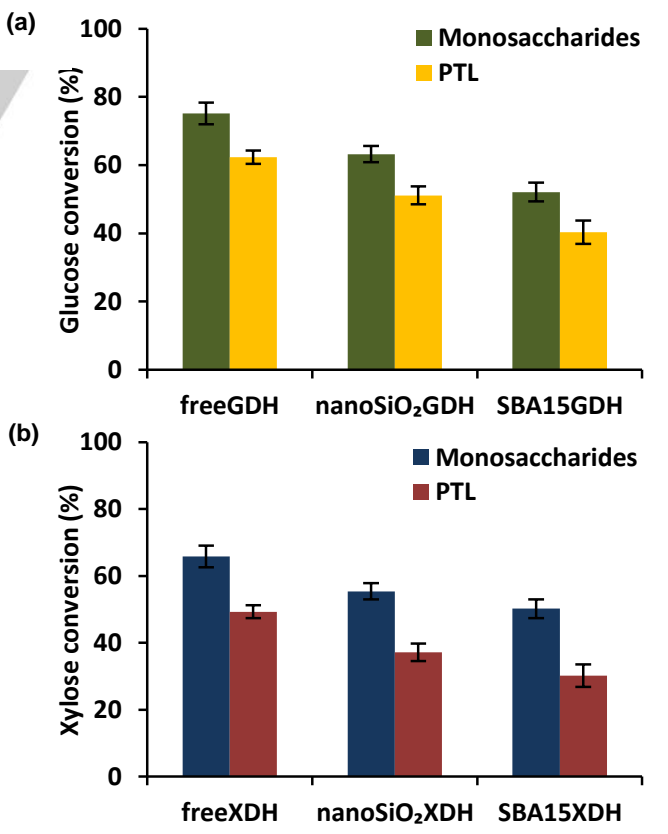

Figure 5. Conversion of (a) glucose to gluconic acid and (b) xylose to xylonic acid catalyzed by free and silica immobilized GDH and XHD, respectively, from monosaccharides solution and pretreated liquor (PTL). Dosage of enzyme: $0.5 \mathrm{mg}$ of free or immobilized GDH or $200 \mathrm{U}$ of free or immobilized $\mathrm{XDH}$. All data are presented as means \pm standard deviation. 
Conversion of glucose to gluconic acid in the stream of monosaccharides by free GDH, nanoSiO ${ }_{2} \mathrm{GDH}$ and SBA15GDH reached 76,64 and $56 \%$, respectively (Fig. 5a), corresponding to biocatalytic productivity values of $17.08,14.41$ and $12.56 \mathrm{mg}$ of gluconic acid per $1 \mathrm{mg}$ of free, nanoSiO $\mathrm{S}_{2}$ or SBA15 immobilized $\mathrm{GDH}$, respectively (Table 4). By contrast, transformation of xylose from the same feed solution was lower and achieved 67,57 and $52 \%$ for free, nanoSiO ${ }_{2} \mathrm{XDH}$ and SBA15XDH, respectively (Fig 5b), corresponding to a biocatalytic productivity of $0.180,0.155$ and $0.141 \mathrm{mg}$ of xylonic acid per $1 \mathrm{U}$ of free, nanoSiO $\mathrm{S}_{2}$ or SBA 15 immobilized $\mathrm{XDH}$, respectively as shown in Table 4 . Higher conversion of glucose to gluconic acid was mainly due to two factors. First of all, a greater amount of GDH was immobilized on silica carriers, moreover, attached GDH exhibited higher specific activity and activity retention compared to immobilized $\mathrm{XDH}$. Second, concentration of glucose was about five times lower than xylose. The drop in conversion of both monosaccharides which was observed for immobilized enzymes compared to the free ones is related to decrease in enzyme activity upon immobilization, and has also been observed in other studies ${ }^{[31,32]}$.

Conversion of glucose and xylose presented in crude PTL (containing inhibitors) followed the same trend (Fig. 5a,b). However, compared to the stream of monosaccharides, in case of the PTL feed solution, about 15 and $20 \%$ lower values of conversion were achieved for glucose and xylose, respectively. This is directly related to the presence of inhibitors, such as formic and acetic acids or furans, in the feed solution, which could inhibit enzyme catalytic properties. The presence of trace amounts of phenols and monovalent $\left(\mathrm{K}^{+}\right.$or $\left.\mathrm{Na}^{+}\right)$or divalent $\left(\mathrm{Mg}^{2+}\right.$ or $\left.\mathrm{Ca}^{2+}\right)$ ions could also affect activity of both enzymes as reported earlier ${ }^{[33]}$. Nevertheless, the results presented clearly show that investigated biocatalytic systems demonstrated efficient conversion of monosaccharides and therefore could find practical applications in the food industry as well as in biorefinery.

\section{Reusability of the free and immobilized GDH and XDH}

One of the great advantages of immobilization is enhancement of enzyme reusability in sequential conversion processes, which leads to decrease in process costs. As can be seen, free GDH and $\mathrm{XDH}$ gradually lost their catalytic properties: GDH was inactivated after four catalytic cycles using a monosaccharides stream and after four cycles using PTL as feed solution, while $\mathrm{XDH}$ was inactivated after three catalytic cycles irrespective of the feed solution used (Fig. 6). On the other hand, immobilized GDH retained around $70 \%$ of its initial activity and immobilized $\mathrm{XDH}$ maintained around $60 \%$ of its catalytic properties after three reaction cycles irrespective of the support material and feed solution. Moreover, after five reaction cycles, GDH and $\mathrm{XDH}$ immobilized onto SBA 15 surface retained over $50 \%$ of their initial activity during conversion of glucose and xylose from monosaccharides solution, and over $40 \%$ of initial catalytic properties when PTL was used as feed solution. This retention of activity was higher than retention obtained when silica nanoparticles were used as carrier, as after five reaction cycles nanoSiO $\mathrm{S}_{2} \mathrm{GDH}$ and nanoSiO $\mathrm{SDH}_{2} \mathrm{XDaintained}$, respectively, only 43 and $39 \%$ of their catalytic properties with monosaccharides solution, and 38 and $33 \%$, respectively, of their catalytic properties with PTL as feed solution.

The above results are in agreement with the data of biocatalytic productivity. After five consecutive reaction cycles, productivity of gluconic acid with the monosaccharides solution as the feed by free $\mathrm{GDH}$ reached $32.11 \mathrm{mg}$ of gluconic acid per $\mathrm{mg}$ of enzyme. Productivity of nanoSiO ${ }_{2} \mathrm{GDH}$ was about 1.6 fold higher $(52.44 \mathrm{mg} / \mathrm{mg})$, while productivity of SBA15GDH was about 1.4 fold higher $(45.61 \mathrm{mg} / \mathrm{mg})$ compared to the free enzyme (Table 4). Even higher increase in biocatalytic productivity of xylose was noticed using silica immobilized XDH and monosaccharides solution. After five reaction steps free $\mathrm{XDH}$ exhibited a productivity of $0.307 \mathrm{mg}$ of xylonic acid per 1 unit of $\mathrm{XDH}$, while productivity of nanoSiO $\mathrm{SDH}_{2}$ and $\mathrm{SBA} 15 \mathrm{XDH}$ was $0.502 \mathrm{mg} / \mathrm{U}$ (1.7 fold) and $0.461 \mathrm{mg} / \mathrm{U}$ (1.6 fold), respectively. It should also be mentioned that lower values of biocatalytic productivity of gluconic and xylonic acid were observed using PTL as a feed solution; this result is directly related to higher concentration of glucose and xylose in PTL compared to in the stream of monosaccharides. These results confirm that reusability of the immobilized GDH and XDH was significantly improved. Nevertheless, it should be emphasised that irrespective of the feed solution used, during initial reaction cycles (up to third cycle), enzymes immobilized onto silica nanoparticles exhibited higher catalytic properties, but in further conversion steps, SBA 15 based systems showed higher activity. This phenomenon could be explained by the fact that enzyme immobilized in pores of hexagonal silica is better protected before inactivation and elution from the matrix, and thus its activity is less affected during the sequential conversion process. Higher retention of catalytic activity by enzymes used for conversion of both glucose and xylose from monosaccharides solution is probably related to the fact that the amount of enzyme inhibitors such as metal ions, inorganic acids and furans was significantly reduced compared to their presence in the PTL solution. Nevertheless, gradual decrease in enzyme activity after just a few catalytic cycles could be explained by several factors, such as enzyme inhibition by product, structural modification of the enzymes as well as by catalyst inactivation caused by their thermal and $\mathrm{pH}$ denaturation ${ }^{[34]}$. It should be also mentioned that due mainly to adsorption interactions, some enzyme leakage from the matrix (up to $30 \%$ after last cycle) also occurred as a contributory factor. Earlier studies reported that glucose-6phosphate dehydrogenase encapsulated in silica-based hydrogels retained less than $40 \%$ of its initial activity just after one reaction cycle $^{[35]}$, as in another study, $40 \%$ of activity retention was observed after seven reaction cycles when glucose-6-phosphate dehydrogenase was immobilized in alginate ${ }^{[23]}$. 
Table 4. Biocatalytic productivity of free and immobilized GDH (mg of gluconic acid per mg of enzyme) and free and immobilized XDH (mg of xylonic acid per $U$ of enzyme) after five consecutive catalytic cycles.

\begin{tabular}{|c|c|c|c|c|c|c|}
\hline \multirow{2}{*}{ Analyzed parameter } & \multicolumn{6}{|c|}{ Biocatalytic productivity (GDH in $\mathrm{mg} / \mathrm{mg}$ ) and (XDH in $\mathrm{mg} / \mathrm{U}$ ) } \\
\hline & freeGDH & nanoSiO ${ }_{2} \mathrm{GDH}$ & SBA15GDH & freeXDH & nanoSiO ${ }_{2}$ XDH & SBA15XDH \\
\hline Monosaccharides & 32.11 & 52.44 & 45.61 & 0.307 & 0.502 & 0.461 \\
\hline PTL & 31.12 & 51.10 & 39.08 & 0.204 & 0.336 & 0.279 \\
\hline
\end{tabular}

(a)

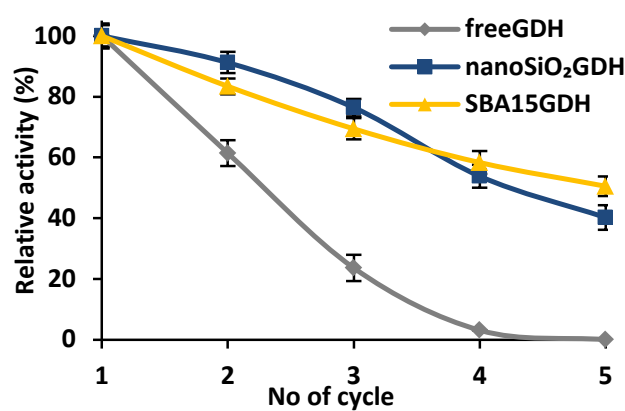

(c)

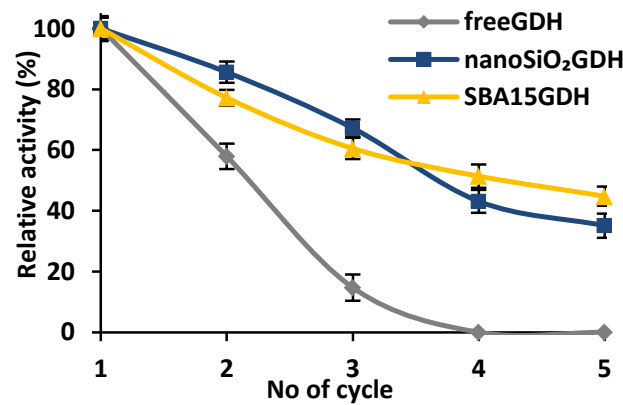

(b)

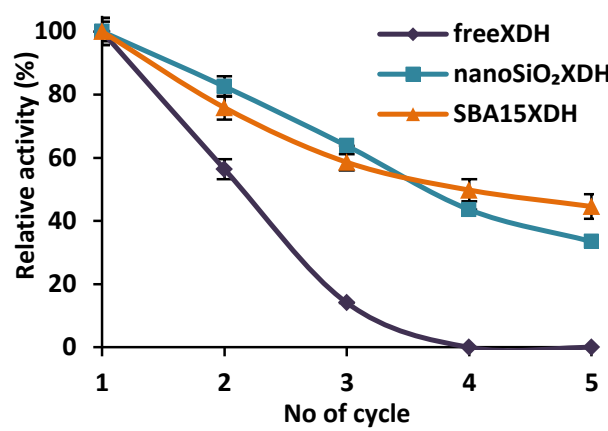

(d)

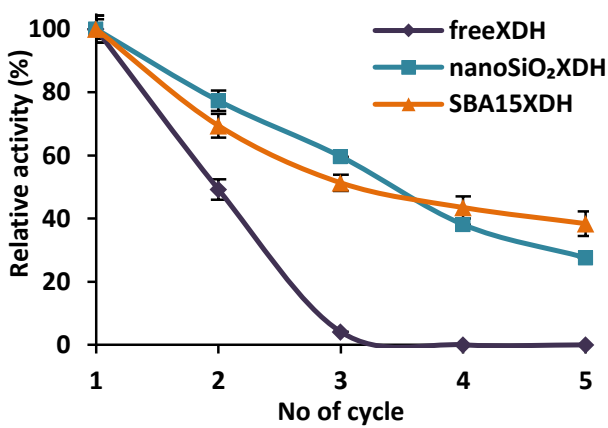

Figure 6. Reusability of the free and silica immobilized GDH and XHD evaluated based on consecutive conversion of glucose and xylose, respectively, using monosaccharides solution after nanofiltration (a) and (b) and PTL (c) and (d) as feed solution. All data are presented as means \pm standard deviation.

\section{Conclusions}

Our study provides proof-of-concept for the immobilization of glucose dehydrogenase (GDH) and xylose dehydrogenase $(\mathrm{XDH})$ on silica nanoparticles and hexagonal mesoporous SBA15 silica, and application of the obtained biocatalytic systems for effective conversion of glucose and xylose from biomass liquors. Specific activity of free $\mathrm{GDH}$ and $\mathrm{XDH}$ (assessed as NADH consumption during reduction of glucose and xylose, respectively) was comparable and reached 42.2 $\mathrm{U} / \mathrm{mg}$ and $46.8 \mathrm{U} / \mathrm{mL}$, respectively. After immobilization, both enzymes exhibited high catalytic activity retention, but better loadings and activity retention were obtained for GDH and XDH immobilized on the surface of silica nanoparticles than on the mesoporous silica particles, which confirms that type of support material affects properties of the biocatalytic systems obtained.
Nevertheless, on both types of silica supports, the immobilized enzymes attained improved thermal stability both silicaimmobilized enzymes are characterized by improved thermal stability, with half-life of SBA15GDH and SBA15XDH being increased 7.25 and 9.5 fold, respectively as compared to free biocatalysts, after incubation for four hours at $45^{\circ} \mathrm{C}$. However, immobilization did not affect the $\mathrm{pH}$ optima of any of the two enzymes, regardless of the type of silica immobilization material, and the immobilized enzymes showed the same high activity over a broad range of $\mathrm{pH}$ (over $50 \%$ activity at $\mathrm{pH}$ range $8-10$ ). Robustness at higher $\mathrm{pH}$, above the $\mathrm{pK}_{\mathrm{a}}$ of gluconic and xylonic acid, is of particular interest, because this feature facilitates simple separation of the gluconic and xylonic acid from reaction mixture even by a simple membrane filtration. Additionally, the immobilized enzymes exhibited improved reusability; not only was their catalytic activity retained after five consecutive reaction cycles but the biocatalytic productivity was improved about 1.6 fold by nanoSiO ${ }_{2} \mathrm{GDH}$ and nanoSiO${ }_{2} \mathrm{XDH}$ compared to the free 
enzymes. The data thus clearly shown that immobilization of $\mathrm{GDH}$ and $\mathrm{XDH}$ is an attractive approach for efficient transformation of glucose and xylose into valuable products. Hopefully, the data may stimulate further development of the use of monosaccharide dehydrogenases in biorefining and separation of monosaccharides in genuine biomass liquors.

\section{Experimental Section}

\section{Chemicals and reagents}

Commercially available silica nanopowder of $10-20 \mathrm{~nm}$ particle size (nanoSiO ${ }_{2}$ ) and mesoporous SBA 15 silica $(<150 \mu \mathrm{m}$ particle size) with hexagonal pore morphology and pore size up to $20 \mathrm{~nm}$ (SBA15) used in this study were provided by Sigma-Aldrich (Steinheim, Germany). Tris$\mathrm{HCl}$ buffer, phosphate buffer, $\beta$-nicotinamide adenine dinucleotide hydrate $(\mathrm{NAD}+), \beta$-nicotinamide adenine dinucleotide, reduced disodium salt hydrate (NADH), D-glucose, D-xylose and glucose dehydrogenase from Pseudomonas sp. (GDH) (EC 1.1.1.118) were purchased from Sigma-Aldrich (Steinheim, Germany). Xylose dehydrogenase (XDH) (EC 1.1.1.175) was provided by Megazyme (Bray, Wicklow, Ireland). All chemicals were of analytical grade and were used as received from the suppliers without further purification.

\section{Real liquors}

The pretreated liquor (PTL) used in this study was obtained after combined acid and hydrothermal pretreatment of the biomass. For pretreatment, diluted sulfuric acid and high temperature steam $\left(180^{\circ} \mathrm{C}\right)$ were injected in the reactor containing soaked wood for a $10 \mathrm{~min}$. After pretreatment, the liquid fraction was separated from the solids by pressing in reactor. Prior to use, the PTL was filtered using the microfiltration membrane GR4OPP (MWCO $100 \mathrm{kDa}$ ) at 4 bar in an Amicon 8050 (Millipore, Burlington, MA, USA) stirred cell to clarify the solution. The concentration of monosaccharides, glucose, xylose and arabinose was $13.3 \mathrm{~g} / \mathrm{L}, 55.2 \mathrm{~g} / \mathrm{L}$, and $2.1 \mathrm{~g} / \mathrm{L}$, respectively. The stream of monosaccharides without inhibitors (inorganic acids and furans) containing glucose $(10.3 \mathrm{~g} / \mathrm{L})$, xylose $(48.8 \mathrm{~g} / \mathrm{L})$ and arabinose $(1.9 \mathrm{~g} / \mathrm{L})$ was obtained after nanofiltration of PTL at 40 bar using a NF90 nanofiltration membrane (MWCO 200-400 Da) in a stainless steel stirred cell (HP4750, Sterlitech Corporation, Kent, WA, USA).

\section{Immobilization of GDH and XDH}

For the immobilization of $\mathrm{GDH}$ and $\mathrm{XDH}, 50 \mathrm{mg}$ of silica nanoparticles or silica SBA 15 was immersed in $2 \mathrm{~mL}$ of enzyme solution in phosphate buffer at $\mathrm{pH} 7$ containing $0.15 \mathrm{mg}(30 \mathrm{U})$ of $\mathrm{GDH}$ or $30 \mathrm{U}$ of $\mathrm{XDH}$. The immobilization was carried out by incubation of the silica support (nanoSiO ${ }_{2}$ or SBA 15) with each enzyme solution for $3 \mathrm{~h}$ at $4^{\circ} \mathrm{C}$ in an IKA KS 4000i control incubator (IKA WerkeGmbH, Germany) with mixing at $200 \mathrm{rpm}$. The immobilized enzymes (nanoSiO ${ }_{2} \mathrm{GDH}$, SBA15GDH, nanoSiO ${ }_{2} \mathrm{XDH}, \mathrm{SBA} 15 \mathrm{XDH}$ ) were recovered from the solution by centrifugation at $4000 \mathrm{rpm}$ for $15 \mathrm{~min}$ (Sigma 4K15, Sigma Laborzentrifugen $\mathrm{GmbH}$ ). The protein content in the samples after immobilization (amount of immobilized enzyme $(\mathrm{mg} / \mathrm{g})$ ) was determined by the Bradford method (eq. 1) as the difference in the initial enzyme dosage protein and the concentration of protein present in the supernatant after immobilization ${ }^{[36]}$ and considering mass of the support material, according to eq. 1. From the results of the Bradford method, immobilization yield (\%) was calculated (eq. 2).

$$
\begin{aligned}
& \text { Amount of immobilized enzyme }=\frac{c_{i} V_{i}-c_{s} V_{s}}{m_{\text {support }}} \\
& \text { Immobilization yield }(\%)=\frac{c_{i} V_{i}-c_{S} V_{S}}{c_{i} V_{i}} \cdot 100 \%
\end{aligned}
$$

where $c_{i}$ and $c_{s}$ denote concentration of enzyme before and after immobilization $(\mathrm{mg} / \mathrm{mL}$ or $\mathrm{U} / \mathrm{mL}), V_{i}$ and $V_{s}$ denote volume of the solution
$(\mathrm{mL})$ before and after immobilization, and $m_{\text {support }}$ is the mass of the support material $(\mathrm{g})$.

\section{GDH and XDH activity}

Activity assays for GDH and XDH were performed spectrophotometrically during kinetic reduction of $\mathrm{NAD}+$ to $\mathrm{NADH}$, as presented below, using a standard calibration curve of $\mathrm{NADH}$. One unit of free or immobilized enzyme activity was defined as the quantity of enzyme required to produce $1 \mu \mathrm{M}$ of NADH per minute under the assay conditions. Specific activity values $(\mathrm{U} / \mathrm{mg})$ of free and immobilized enzymes are presented as initial enzyme activity retained per unit mass of enzyme, and per unit mass of enzyme and solid support, respectively. The activity retention (\%) of immobilized enzyme was defined as the percentage activity of the immobilized GDH and $\mathrm{XDH}$ compared to the catalytic activity of free enzymes. All measurements were done in triplicate and error bars are presented as means \pm standard deviation.

\section{GDH activity assay}

Catalytic activity of free and immobilized GDH was evaluated spectrophotometrically by measuring the absorbance at $\lambda=340 \mathrm{~nm}$ (Shimadzu UV1280, Shimadzu, Japan) during kinetic reduction of NAD+ to $\mathrm{NADH}$. The reaction was carried out for $2 \mathrm{~min}$ in a styrene cuvette with a volume of $1 \mathrm{~mL}$ of reaction mixture containing $20 \mathrm{U}$ of free or immobilized GDH, $3 \mathrm{mM} \mathrm{NAD+}$ and $50 \mathrm{mM}$ D-glucose in Tris- $\mathrm{HCl}$ buffer at $\mathrm{pH} 8,45^{\circ} \mathrm{C}$.

\section{XDH activity assay}

Activity of free and immobilized XDH was determined spectrophotometrically by following changes in the absorbance at $\lambda=340$ $\mathrm{nm}$ during kinetic reduction of $\mathrm{NAD}+$ to $\mathrm{NADH}^{[37]}$. The reaction was carried out in a styrene cuvette with a volume of $1 \mathrm{~mL}$ of reaction mixture containing $30 \mathrm{U}$ of free or immobilized $\mathrm{XDH}, 3 \mathrm{mM} \mathrm{NAD+}$ and $70 \mathrm{mM}$ D-xylose in Tris- $\mathrm{HCl}$ buffer at $\mathrm{pH} 8$ for 2 min at $45^{\circ} \mathrm{C}$.

\section{$\mathrm{pH}$ profiles of free and immobilized enzymes}

The $\mathrm{pH}$ profiles of free and immobilized GDH and $\mathrm{XDH}$ were examined using the methodology described above, at $\mathrm{pH}$ values ranging from 6 to 10 at $45^{\circ} \mathrm{C}$. The $\mathrm{pH}$ of the solution was adjusted using $0.1 \mathrm{M} \mathrm{HCl}$ and $0.1 \mathrm{M} \mathrm{NaOH}$. All measurements were made in triplicate and error bars are presented as means \pm standard deviation.

\section{Temperature profiles of free and immobilized enzymes}

The temperature profiles of free and immobilized glucose dehydrogenase and xylose dehydrogenase were evaluated based on the abovementioned methodology at temperatures varying from $30^{\circ} \mathrm{C}$ to $60^{\circ} \mathrm{C}$ in steps of $5^{\circ} \mathrm{C}$, at $\mathrm{pH} 8$. Prior to spectrophotometric measurements, free and immobilized enzymes were incubated at the desired temperature for $30 \mathrm{~min}$. All measurements were made in triplicate and error bars are presented as means \pm standard deviation.

\section{Stability of free and immobilized enzymes}

Stability of both free and immobilized enzyme over time was evaluated after incubating the native and immobilized enzymes for 240 min under optimum $\mathrm{pH}$ and temperature conditions. For free and silica immobilized $\mathrm{GDH}$, the optima were $45^{\circ} \mathrm{C}$ and $\mathrm{pH} 8$, while for free and silica immobilized $\mathrm{XDH}$, the optima were $\mathrm{pH} 8$ and $40^{\circ} \mathrm{C}$ and $\mathrm{pH} 8$ and $45^{\circ} \mathrm{C}$ respectively. The relative activity of free and immobilized enzyme was further determined after a specified period of time. The initial activity of free $\mathrm{GDH}$ and $\mathrm{XDH}$ was defined as $100 \%$ activity. The inactivation constant $\left(k_{D}\right)$,and half-life $\left(t_{1 / 2}\right)$ were evaluated based on the linear regression slope. All measurements were made in triplicate and error bars are presented as means \pm standard deviation.

\section{Kinetic parameters of free and immobilized enzymes}

Examination of the kinetic parameters - the Michaelis-Menten constant $\left(K_{M}\right)$, maximum reaction rate $\left(V_{\max }\right)$, turnover number $\left(k_{c a t}\right)$ and specificity constant $\left(k_{c a t} / K_{M}\right)$ - of free and immobilized $\mathrm{GDH}$ and $\mathrm{XDH}$ was 
performed based on the model enzymatic reactions (see section GDH and XDH activity), using various concentrations of NAD+. The kinetic parameters were calculated based on Hanes-Wolf plots under optimum assay conditions.

\section{Glucose and xylose conversion}

In the presented study, two biomass liquors were used which contained monosaccharides only (monosaccharides stream) and monosaccharides with inhibitors (PTL) (see section Real liquors). The reaction was performed in glass tubes. For the reaction, $1 \mathrm{~mL}$ of monosaccharides solution or PTL was used to which was added $0.5 \mathrm{mg}$ of free or immobilized GDH or $200 \mathrm{U}$ of free or immobilized XDH and $10 \mathrm{mM}$ of $\mathrm{NAD}+$. Prior to the reaction, the $\mathrm{pH}$ of reaction mixture was adjusted to 8 and to 8.5 for $\mathrm{GDH}$ and $\mathrm{XDH}$, respectively using $0.1 \mathrm{M} \mathrm{NaOH}$. After $30 \mathrm{~min}$ of the process, the reaction was terminated by addition of $2 \mathrm{~mL}$ of $1 \mathrm{M} \mathrm{HCl}$ and the mixture was subjected to HPLC analysis.

Conversion of glucose to gluconic acid by GDH and xylose to xylonic acid by XDH was evaluated based on the results of High Performance Liquid Chromatography (HPLC) and calculated using eq. 3. Shimadzu Corp. (Japan) equipment was used in the HPLC-analysis (LC-20AD, DGU-20A3, SIL-20AC, SCL-10A, CTO-10A). The column system consisted of an Aminex HPX-87H lon Exclusion Column $(300 \mathrm{~mm} \times$ $8.7 \mathrm{~mm}$ ) (Bio-Rad) and a security guard $(\mathrm{H}+)$ pre-column. The temperature was $63^{\circ} \mathrm{C}$, the eluent was $4 \mathrm{mM} \mathrm{H}_{2} \mathrm{SO}_{4}$ and the flow rate was $0.6 \mathrm{~mL} / \mathrm{min}$. Carbohydrates and acids were detected using a refractive index detector (RID-10A). Samples were diluted with the eluent to obtain concentrations of monosaccharides, and acids in the range of $0.05-5 \mathrm{~g} / \mathrm{L}$ and $0.025-3 \mathrm{~g} / \mathrm{L}$, respectively.

$$
\text { Conversion }(\%)=\frac{C_{F}-C_{P}}{C_{F}} \cdot 100 \%
$$

where $C_{F}$ and $C_{P}$ denotes xylose or glucose concentration $(\mathrm{g} / \mathrm{L})$ in feed solution and after enzymatic conversion, respectively.

\section{Reusability study of free and immobilized enzymes}

The reusability of the free and immobilized GDH and XDH was examined by measuring conversion of xylose and glucose in the stream of monosaccharides and pretreated liquor, according to methodology presented in the above section, over five consecutive reaction cycles. After each conversion cycle, the immobilized GDH and XDH was separated from the reaction mixture by centrifugation and washed with Tris- $\mathrm{HCl}$ buffer solution before the next cycle. Free enzyme was separated from the reaction mixture by nanofiltration at 4 bar in an Amicon 8050 (Millipore, USA) using an NF90 membrane. The conversion of glucose and xylose by GDH and XDH, respectively, in the first catalytic cycle was defined as $100 \%$. The biocatalytic productivity of free and immobilized enzyme was expressed as mass of product formed $(\mathrm{mg})$ by mass of the enzyme used.

\section{Statistical analysis}

Statistically significant differences were determined by one-way ANOVA performed in SigmaPlot 12 (Systat Software Inc., USA) using Tukey's test. Statistical significance was established at a $p<0.05$ level.

\section{Acknowledgements}

This work was supported by research grant funds from the National Science Center Poland in accordance with decision no. DEC-2016/20/T/ST8/00391.

Keywords: glucose dehydrogenase, xylose dehydrogenase, enzyme immobilization, silica, biomass conversion
[1] B.V. Twala, B.T. Sewell, J. Jordaan, Enzyme and Microbial Technology, 2012, 50, 331-336.

[2] T. Pongtharangkul, P. Chuekitkumchorn, N. Suwanampa, P. Payongsri, K. Honda, W. Panbangred, AMB Express, 2015, 5, 68-79.

[3] S. Ferri, K. Kojima, K. Sode, Journal of Diabetes Science and Technology, 2011, 5, 1068-1076.

[4] S.T. Morthensen, A.S. Meyer, H. Jørgensen, M. Pinelo, Biochemical Engineering Journal, 2017, 117, 41-47.

[5] T. Werpy, G. Petersen, U.S. Department of Energy, National Renewable Energy Laboratory, 2004.

[6] S. Ramachandran, P. Fontanille, A. Pandey, C. Larroche, Food Technology and Biotechnology, 2006, 44, 185-195.

[7] W. Niu, M.N. Molefe, J.W. Frost, Journal of American Chemical Society, 2003, 125, 12998-12999.

[8] H. Liu, K.N.G. Valdehuesa, G.M. Nisola, K.R.M. Ramos, W.J. Chung, Bioresource Technology, 2012, 115, 244-248.

[9] J. Atalah, Y. Zhou, G. Espina, J.M. Blamey, R.P. Ramasamy, Catalysis Science and Technology, 2018, 8, 1272.

[10] K.Murai, T. Nonoyama, T. Saito, K. Kato, Catalysis Science and Technology, 2012, 2, 310.

[11] J. Zdarta, A.S. Meyer, T. Jesionowski, M. Pinelo, Advances in Colloid and Interface Science, 2018, 258, 1-20.

[12] J. Zdarta, K. Antecka, R. Frankowski, A. Zgoła-Grześkowiak, H. Ehrlich T. Jesionowski, Science of the Total Environment, 2018, 615, 784-795.

[13] M. Markiton, S. Boncel, D. Janas, A. Chrobok, ACS Sustainable Chemistry and Engineering, 2017, 5, 1685-1691.

[14] P.F. Fulvio, S. Pikus, M. Jaroniec, Journal of Colloid and Interface Science, 2005, 287, 717-720.

[15] J. Zdarta, A.S. Meyer, T. Jesionowski, M. Pinelo, Catalysts, 2018, 8, 92

[16] P. Zucca, E. Sanjust, Molecules, 2014, 19, 14139-14194.

[17] K. Yamanaka, M. Gino, R. Kaneda, Agricultural and Biological Chemistry, 1977, 41, 1493-1499.

[18] P.K. Srivastava, S. Singh, Preparative Biochemistry and Biotechnology, 2013, 43, 376-384.

[19] L. Li, B. Liang, F. Li, J. Shi, M. Mascini, Q. Lang, A. Liu, Biosensors and Bioelectronics, 2013, 42, 156-162.

[20] M. Baron, J.D. Fontana, M.F. Guimaraes, J. Woodward, Appllied Biochemistry and Biotechnology, 1997, 63, 257-268.

[21] N. Aissaoui, J. Landoulsi, L. Bergaoui, S. Boujdaya, J. Lambert, Enzyme and Microbial Technology, 2013, 52, 336-343.

[22] C.M. Moore, N.L Akers, A.D. Hill, Z.C. Johnson, S.D. Minteer, Biomacromolecules, 2004, 5, 1241-1247.

[23] F. Secudno, Chemical Society Reviews, 2013, 42, 6250-6261.

[24] H. Li, W. Xiao, P. Xie, L. Zheng,Enzyme and Microbial Technology, 2018, 10, 66-73

[25] S. Singh, P.K. Srivastava, Advances in Enzyme Research, 2014, 2, 134-149.

[26] N.N. Mubarak, J.R. Wong, K.W. Tan, J.N. Sahu, E.C. Abdullah, N.N Jayakumar, P. Ganesan, Journal of Molecular Catalysis B: Enzymatic, 2014, 107, 124-131.

[27] Q.Z.K. Zhou, X.D. Chen, Biochemical Engineering Journal, 2001, 9, 33-40.

[28] Q.Z.K. Zhou, X.D. Chen, Journal of Food Engineering, 2001, 48, 69-74.

[29] F. Marpani, Z. Sarossy, M. Pinelo, A.S. Meyer, Biotechnology and Bioengineering, 2017, 117, 2762-2770.

[30] S.A. Yamanaka, B. Dunn, J.S. Valentine, J.I. Zink, Journal of American Chemical Society, 1995, 117, 9095-9096.

[31] M. Zheng, Z. Su, X. Ji, G. Ma, P. Wang, S. Zhang, Journal of Biotechnology, 2013, 168, 212-217.

[32] S. Sahin, I. Ozmen, Journal of Molecular Catalysis B: Enzymatic, 2016 133, S25-S33

[33] P.L. James, C. Anthony, BiophysicaActa, 2003, 1674, 200-205.

[34] J. Jordan, C.S.S.R. Kumar, C. Theegala, Journal of Molecular Catalysis B: Enzymatic, 2011, 68, 139-146.

[35] S. Cumana, I. Ardao, A.P. Zeng, I. Smirnova, Engineering in Life Sciences, 2014, 14, 170-179.

[36] M.M. Bradford, Analytical Biochemistry, 1976, 72, 248-.254

[37] C.L. Lee, R.E. Kibblewhite, C.D. Paavola, W.J. Orts, K. Wagschal, Journal of Microbiology and Biotechnology, 2017, 27, 77-83. 


\section{FULL PAPER}

Immobilization of glucose and xylose dehydrogenase using silica-based support materials improved enzymes stability and reusability as well as enhanced efficient conversion of biomass components in bioreactors, under mild conditions.

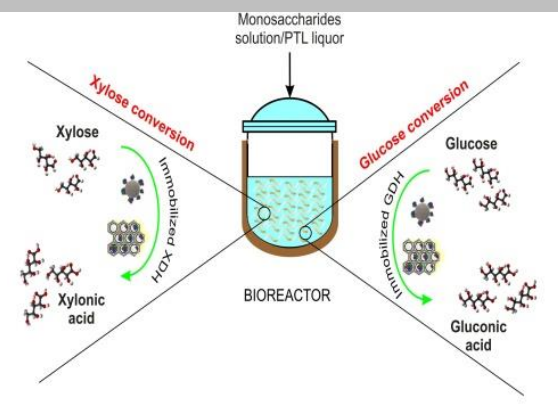

Jakub Zdarta*, Manuel Pinelo, Teofil Jesionowski, Anne S. Meyer

Page No. - Page No.

Upgrading of biomass

monosaccharides by immobilized glucose dehydrogenase and xylose dehydrogenase 